\title{
Accounting
}

\section{Ownership of local corporations and audit committee diligence: An empirical evidence from an emerging economy}

\author{
Khaled Salmen Aljaaidi ${ }^{a^{*}}$
}

${ }^{a}$ Assistant Professor, Accounting Department, College of Business Administration, Prince Sattam bin Abdulaziz University, Saudi Arabia

\begin{tabular}{l} 
C H R O N I C L E \\
\hline Article history: \\
Received: January 15, 2021 \\
Received in revised format: \\
January 28 2021 \\
Accepted: February 24, 2021 \\
Available online: \\
February 24, 2021 \\
\hline Keywords: \\
Audit committee diligence \\
Local corporate ownership \\
Saudi Arabia
\end{tabular}

\section{A B S T R A C T}

This study examines whether local corporate ownership is associated with audit committee diligence among 431 listed manufactured firms in Saudi Stock Exchange (Tadawul) for the period 2012-2019. Using the complementary hypothesis, this study expected that there is a positive relationship between local corporate ownership and audit committee diligence. The Pooled OLS regression shows that local corporate ownership is positively associated with audit committee diligence. The findings reported by this study have implications for regulators, companies' management, auditors, and creditors in a manner that they would gain a deeper understanding on how the local corporate ownership impacts the audit committee diligence.

(C) 2021 by the authors; licensee Growing Science, Canada

\section{Introduction}

The need for corporate governance is as a result of the possibility of the interests of various stakeholders conflicting. The common term used for such conflicts of interests across the corporate structure is agency problems. Agency problems have two main sources which include, difference in preferences and goals among stakeholders and stakeholders not clearly knowing each other's preferences, knowledge and actions (Gillan \& Starks, 2003). It is mandatory for corporations to have audit committees since many large companies have collapsed over years. Majority of the collapses are widely as a result of absence of effective corporate governance (Leung \& Cooper, 2003). The Saudi Corporate Governance Code designates the audit committee as one of the most crucial mechanisms for internal governance. In numerous previous studies, how many diligences an audit committee holds over a certain period of time shows its effectiveness but it can also measure its meticulousness (Kyereboah-Coleman, 2007; Mohid Rahmat et al., 2009). The rate of occurrence of the audit committee diligence can be instigated as a means to ensure the committee's aptitude. In some entrenched corporations the frequency of the diligence can also be used to keep an eye on the benefits of financial reporting of the company (DeZoort et al., 2002). The activeness of an audit committee is measured by its ability to send out a positive signal regarding how good the financial information of a company is, especially where sizable agency costs are involved (Dey, 2008). Previous literature on issues of an audit committee describes an effective audit committee as one that guarantees efficient risk management, proper in-house control, and precise financial reporting for that particular organization. Additionally, an active audit committee promotes transparent security markets which in turn improve the book value of a company and protects the interests of shareholders (Astuti, Fachrurrozie, Amal \& Zahra, 2020; Rahman, Meah \&

* Corresponding author. Tel: +966 503831531

E-mail address: k.aljaaidi@psau.edu.sa (K. S. Aljaaidi) 
Chaudhory, 2019; Yin et al., 2012; McMullen \& Raghunandam, 1996; DeZoort et al., 2002; Bagais \& Aljaaidi, 2020; Habtoor, Hassan \& Aljaaidi, 2019; Hassan, Aljaaidi, Abidin and Nasser, 2018).

This study is aimed at testing the relationship between audit committee diligence and local company ownership. Specifically, in many emerging countries local companies are amongst the prevalent group of block-holders (Claessens et al., 2000). Corporate ownership is quite beneficial to inter-corporation alliances since it saves them money by decreasing the monitoring costs of the associations or endeavors between businesses and their corporate block holders (Allen and Phillips, 2000). It also points out that local investors provide more financial, organizational, and technical resources than foreign investors (Chibber \& Majumdar, 1999; Djankov \& Hoekman, 2000; Khanna \& Palepu, 2000). In addition, the local trade and administrative ties are usually the influencers of the monitoring roles played by local investors (Claessens et al., 2000; Dharwadkar, George \& Brandes, 2000; Douma et al., 2006).

Saudi Arabia offers fundamental equity ownership to local organizations. The local corporations are often allowed to designate members who act as representatives in the board of directors of organizations that disclose to them internal information. These representatives are called insiders. Dominance over local companies affects corporate governance practice along with the management of companies since it denies managers the supple independence and the objective to keep the internal processes of a company in check. Additionally, a corporate governance structure dominated by local corporate ownership is more preferable to investors due to deficiency of robust protection on investor and more so, Saudi Arabia faces underdevelopment in the corporate control market (Chahine \& Tohme, 2009; Alsaeed, 2006; Al-Shammari et al., 2008; Omran et al., 2008). A study by Chahine (2007) indicates that corporations within the Gulf Cooperation Council (GCC), are likely to have poor decision-making processes and erroneous communication dominating how board members play their administrative role since the board members rely and associate strongly with the owners.

This study uses the complementary hypothesis to predict the relationship between the local corporate ownership and audit committee diligence, expecting that local corporate ownership is interrelated with an audit committee meeting. The corporate governance mechanisms, namely; the ownership of local companies and audit committee diligence become more effective when they are combined together. O'Sullivan et al. (2008) and Hassan et al. (2017) indicated that examining the corporate governance mechanisms as an overall and not individually gives a stronger effect. As a consequence, the shareholder interests are protected because these governance mechanisms act in a complementary or substitutable fashion (Ward et al., 2009; Agrawal and Knoeber, 1996; Omer et al., 2020). Empirically, a few studies that have investigated the determinants of audit committee meeting (Aljaaidi, Bagais \& Adow, 2021; Aljaaidi, Sharma \& Bagais, 2021; Aljaaidi \& Bagais, 2021; Menon \& Williams, 1994; Mendez \& Garcia, 2007; Raghunandan \& Rama, 2007; Sharma et al., 2009; Greco, 2011; Al-Najjar, 2011; Thiruvadi, 2012; Yin et al., 2012; Maraghni and Nekhili, 2014; Braswell, Daniels, Landis \& Chang, 2012). The studies used in this paper were carried out in various developed and developing countries due to lack of enough evidence from Saudi Arabia. Moreover, most of the results from the studies were contradictory and lacking, bringing about the need for further empirical inquiries on issues pertaining to the meticulousness of the audit committees. The researcher utilized various resources but found no existence of literature on impacts of local corporate ownership on audit committee diligence. Therefore, this study contributes to the corporate governance literature by incorporating recent data as an extension of the existing research on rate of recurrence of the audit committee diligence.

The remainder of the paper is organized as follows. The next section describes the sample, data and model of the study. Fourth section presents the results, tests and analysis. The final section concludes the study.

\section{Research design and model specification}

The population relevant to the study is all the manufacturing companies listed on the Saudi Stock Exchange (Tadawul) for the years 2012-2019. A cross sectional review of audit reports of the sampled companies listed on Tadawul was undertaken. Samples selected are depicted in Table 1.

\section{Table 1}

Sample Selection

\begin{tabular}{lc}
\hline & Total Observations \\
\hline Total observations & 465 \\
Observations discarded (outliers, missing and incomplete data) & $(34)$ \\
Final sample & 431 \\
\hline
\end{tabular}

The model of this study uses four control variables; board meeting, firm performance, leverage, and firm size. The extant research indicated that these control variables are associated with corporate governance structure. The previous studies pointed 
out to a positive relationship between board meetings and audit committee meetings (Maraghni \& Nekhili, 2014; Thiruvadi, 2012; Raghunandan \& Rama, 2007). It was reported that there is a negative relationship between firm performance and audit committee meetings (Raghunandan and Rama, 2007; Sharma et al., 2009; Yin et al., 2012; Qasim, 2020). In addition, it is documentd that there is a negative association between firm leverage and audit committee meetings (Yin et al., 2012; Me'ndez and Garci'a, 2007). Further, prior research indicated a positive relationship between firm size and audit committee meeting (Yin et al., 2012; Raghunandan \& Rama, 2007; Me'ndez \& Garc1'a, 2007; Deli \& Gillan 2000; Sharma et al. 2009; Maraghni and Nekhili, 2014; Qasim, 2020; Braswell et al., 2012). Due to the continuous nature of the dependent variable, Pooled Ordinary Least Square OLS was utilized as the method of analysis to test the hypothesis. The OLS model can be formulated as following:

$$
\mathrm{ACDIL}=\beta_{0}+\beta_{1} \mathrm{DCOWN}+\beta_{2} \text { BDMEET }+\beta_{3} \mathrm{ROA}+\beta_{4} \mathrm{LEV}+\beta_{5} \text { FSIZE }+\mathrm{e}
$$

where

$\begin{array}{ll}\text { ACDIL } & =\text { Number of meetings held during the year } \\ \text { DCOWN } & =\text { Percentage of common shares held by local companies } \\ \text { BDMEET } & =\text { Number of board meetings held during the year } \\ \text { ROA } & =\text { Return on assets } \\ \text { LEV } & =\text { Total book value of debt to total assets ratio } \\ \text { FSIZE } & =\text { Log } 10 \text { of total assets } \\ \mathrm{e} & =\text { error term. }\end{array}$

As for the measurements of the variables, Table 2 exhibits the dependent and test variables.

\section{Table 2}

Summary of the Operationalization of the Research Variables

\begin{tabular}{|c|c|c|c|}
\hline Variables & Acronym & Operationalization & Type of variable \\
\hline \multicolumn{4}{|l|}{ Dependent Variable } \\
\hline Audit committee activity & $A C D I L$ & Number of meetings held during the year & d.v \\
\hline \multicolumn{4}{|l|}{ Hypothesized variable } \\
\hline Local companies' ownership & DCOWN & Percentage of common shares held by local firms & i.v \\
\hline \multicolumn{4}{|l|}{ Control variables } \\
\hline Board meeting & BDMEET & Number of meetings held during the year & i.v \\
\hline Firm performance & ROA & Return on assets & i.v \\
\hline Firm leverage & LEV & Total book value of debt to total assets ratio & i.v \\
\hline Firm size & FSIZE & $\log _{10}$ of total assets & \\
\hline
\end{tabular}

Note: d.v - dependent variable, i.v - independent variable

\section{Results and discussions}

\subsection{Descriptive statistics and correlation analysis}

The descriptive statistics are presented in Table 3, showing the mean, standard deviation, minimum and maximum of each variable in the sample data set.

Table 3

Descriptive statistics

\begin{tabular}{ccccc}
\hline & Minimum & Maximum & Mean & Std.Deviation \\
\hline DCOWN & .00 & .880 & .18604 & 2.14453 \\
ACDIL & 2 & 12 & 5 & 1.55894 \\
BDMEET & 2 & 22 & 5 & 2.14453 \\
ROA & -.51 & 1.00 & .5062 & .32358 \\
LEV & .00 & .86 & .2670 & .20453 \\
FSIZE & 35461604 & 340041000000 & 13519849111 & 45180718146 \\
\hline
\end{tabular}

Table 3 displays that there is a significant range of variation among the considered samples of this study. Table 3 shows that the range of DCOWN ranges from .00 to .880 with a mean of .18604 and a standard deviation of 2.14453 . ACDIL is from 2 to 12 
with an average of 5 and a standard deviation of 1.55894. The mean of BDMEET is 5 and it ranges from 2 to 22 and a standard deviation of 2.14453. The ROA ranges from -.51 to 1.00 with an average of .5062 and a standard deviation of .32358. As for the LEV, the mean is .2670 and it ranges from .00 to .86 and a standard deviation of .20453 . The FSIZE ranges from 35461604 to 340041000000 with an average of 13519849111 and a standard deviation of 45180718146 .

Table 4

Correlation matrix of independent variables

\begin{tabular}{|c|c|c|c|c|c|}
\hline & DCOWN & BDMEET & ROA & LEV & FSIZE \\
\hline DCOWN & 1 & & & & \\
\hline BDMEET & $.184 * *$ & 1 & & & \\
\hline ROA & $-.155^{*}$ & .058 & 1 & & \\
\hline LEV & .041 & -.078 & $-.739 * *$ & 1 & \\
\hline FSIZE & $.341^{* *}$ & -.012 & $-.516 * *$ & $.369 * *$ & 1 \\
\hline
\end{tabular}

Table 4 confirms that the multicollinearity problem does not exist because the correlation matrixes among the variables do not exceed 0.90. All the variables have a correlation of equal to or less than .739.

\subsection{Multivariate analysis}

Table 5

Audit committee diligence regression model

\begin{tabular}{lccc}
\hline Variables & Expected Sign & Coef. & $t$ \\
\hline Hypothesized Variable & & & \\
DCOWN & + & 1.422 & 2.358 \\
Control variables & & & $\mathbf{. 0 1 9}$ \\
BDMEET & & .288 & 6.297 \\
ROA & -1.368 & -2.243 & $\mathbf{. 0 0 1}$ \\
LEV & -.878 & -1.023 & $\mathbf{. 0 2 6}$ \\
FSIZE & -.704 & -3.185 & $\mathbf{. 0 0 2}$ \\
\hline
\end{tabular}

$\begin{array}{ll}F & 11.64 \\ \text { Adjusted } R^{2} & 20.3 \\ P \text {-value } & 0.001\end{array}$

Bold $=$ significance at $1 \%, 5 \%$ and $10 \%$ (two-tailed significance)

Table 5 reports the multiple regression results. As shown from Table 5, the model explains $20.3 \%$ of the variation in the audit committee diligence. The model is significant $(\mathrm{F}=11.4)$ and (Sign $\mathrm{F}=0.001)$. as for the association between local corporate ownership and audit committee diligence, the direction of this relationship is positive and significant in the predicted direction at $1 \%(\beta=1.422, \mathrm{t}=2.358, \mathrm{P}=.019$, one-tailed significance $)$. This result gives support to the complementary hypothesis. This indicates that local corporate ownership as a governance monitoring mechanism becomes more effective through mutual enhancement and the synergistic effects when it is combined with audit committee diligence as another governance monitoring mechanism. In addition, the effectiveness of local corporate ownership as a monitoring mechanism depends on the effectiveness of the audit committee.

\section{Summary and conclusion}

The primary objective of this study was to examine empirically whether local corporate ownership impacts the audit committee diligence among 431 Saudi manufactured corporations listed on Saudi Stock Exchange (Tadawul) for the period 2012-2019. This study reports that local corporate ownership is positively associated with audit committee diligence. This result is concurrent with the earlier predicted hypothesis which points out that the effectiveness of the local corporate ownership is complimented by audit committee diligence as an additional governance monitoring mechanism. Therefore, the two governance monitoring mechanisms are often interdependent. Therefore, this study provides an additional empirical evidence to the literature body of corporate governance. 
This study is important since it unveils the correlation between audit committee diligences and local corporate ownership in Saudi Arabia. The country's regulators can utilize the findings of this study to introduce protocols that can promote better corporate governance practices. Various limitations were encountered while conducting this study. The main limitation was that the data used was from Saudi Arabia hence generalization of findings to other markets must be cautious due to variation in regulations and economic physiognomies. This study creates a baseline for researchers interested in other classifications of ownership such as institutional, governmental and family ownership. Moreover, Additional research may also be based on other audit committee features such as financial expertise, their independence, or committee size. Furthermore, the setting of the research must not be necessarily Saudi Arabia. The study can be replicated to contexts of other countries within the GCC.

\section{References}

Agrawal, A., \& Knoeber, C. R. (1996). Firm performance and mechanisms to control agency problems between managers and shareholders. Journal of Financial and Quantitative Analysis, 31(3), 377-397.

Aljaaidi, K. S., \& Hassan, W. K. (2020). Energy industry performance in Saudi Arabia: Empirical evidence. International Journal of Energy Economics and Policy, 10(4), 271-277.

Aljaaidi, K. S., Bagais, O. A., \& Adow, A. H. E. (2021). The impact of board activity on the audit committee's effectiveness score: Empirical evidence from Saudi Arabia. The Journal of Asian Finance, Economics, and Business, 8(1), $179-185$.

Aljaaidi, K., \& Bagais, O. (2021). The effect of company performance on audit committee diligence: The case of manufacturing companies in Saudi Arabia. Accounting, 7(2), 391-394.

Aljaaidi, K., Sharma, R., \& Bagais, O. (2021). The effect of board characteristics on the audit committee meeting frequency. Accounting, 7(4), 899-906.

Al-Najjar, B. (2012). The determinants of board meetings: evidence from categorical analysis. Journal of Applied Accounting Research, 13(2), 178-190

Alsaeed, K. (2006). The association between firm-specific characteristics and disclosure. Managerial Auditing Journal, 21(5).

Al-Shammari, B., Brown, P., \& Tarca, A. (2008). An investigation of compliance with international accounting standards by listed companies in the Gulf Co-Operation Council member states. The International Journal of Accounting, 43(4), $425-447$.

ASTUTI, R. N., FACHRURROZIE, F., AMAL, M. I., \& ZAHRA, S. F. (2020). Does Audit Committee Quality Mediate Determinants of Intellectual Capital Disclosure? The Journal of Asian Finance, Economics, and Business, 7(7), 199-208 .

Bagais, O., \& Aljaaidi, K. (2020). Corporate governance attributes and firm performance in Saudi Arabia. Accounting, 6(6), 923-930.

Braswell, M., Daniels, R. B., Landis, M., \& Chang, C. C. A. (2012). Characteristics of diligent audit committees. Journal of Business \& Economics Research (JBER), 10(4), 191-206.

Chahine, S., \& Tohmé, N. S. (2009). Is CEO duality always negative? An exploration of CEO duality and ownership structure in the Arab IPO context. Corporate Governance: An International Review, 17(2), 123-141.

Claessens, S., Djankov, S., \& Lang, L. H. (2000). The separation of ownership and control in East Asian corporations. Journal of financial Economics, 58(1-2), 81-112.

Dey, A. (2008). Corporate governance and agency conflicts. Journal of Accounting Research, 46(5), $1143-1181$.

DeZoort, F. T., Hermanson, D. R., Archambeault, D. S., \& Reed, S. A. (2002). Audit committee effectiveness: A synthesis of the empirical audit committee literature. Audit Committee Effectiveness: A Synthesis of the Empirical Audit Committee Literature, 21, 38 .

Dharwadkar, B., George, G., \& Brandes, P. (2000). Privatization in emerging economies: An agency theory perspective. Academy of Management Review, 25(3), 650-669.

Douma, S., George, R., \& Kabir, R. (2006). Foreign and domestic ownership, business groups, and firm performance: Evidence from a large emerging market. Strategic Management Journal, 27(7), 637-657.

Gillan, S., \& Starks, L. T. (2003). Corporate governance, corporate ownership, and the role of institutional investors: A global perspective. Weinberg Center for Corporate Governance Working Paper.(01-2003),

Greco, G. (2011). Determinants of board and audit committee meeting frequency. Managerial Auditing Journal, 26(3), 208-229

Habtoor, O., Hassan, W., \& Aljaaidi, K. (2019). The relationship between board committees and corporate risk disclosure in Saudi listed companies. International Journal of Advanced and Applied Sciences, 6(12), 41-57.

Hassan, W. K., Aljaaidi, K. S., Bin Abidin, S., \& Nasser, A. M. (2018). Internal corporate governance mechanisms and audit quality: Evidence from GCC region. International Journal of Advanced and Applied Sciences, 5(8), $72-90$.

Hassan, Y., Hijazi, R., \& Naser, K. (2017). Does audit committee substitute or complement other corporate governance mechanisms. Managerial Auditing Journal, 32(7).

Khanna, T., \& Palepu, K. (2000). The future of business groups in emerging markets: Long-run evidence from Chile. Academy of Management Journal, 43(3), 268-285.

Kyereboah-Coleman, A. (2007). The impact of capital structure on the performance of microfinance institutions. The Journal of Risk Finance. 
Leung, P., Cooper, B. J., \& Robertson, P. T. (2003). The role of internal audit in corporate governance \& management. School of Accounting and Law, RMIT University.

Maraghni, I., \& Nekhili, M. (2014). Audit committee diligence in French companies: a question of independence or competence? Comptabilité-Contrôle-Audit, 20(2), 95-124.

McMullen, D. A., \& Raghunandan, K. (1996). Enhancing audit committee effectiveness. Journal of Accountancy, $182(2)$, 79.

Méndez, C. F., \& García, R. A. (2007). The effects of ownership structure and board composition on the audit committee meeting frequency: Spanish evidence. Corporate Governance: An International Review, 15(5), 909-922.

Menon, K., \& Williams, J. D. (1994). The use of audit committees for monitoring. Journal of Accounting and Public Policy, 13(2), 121-139.

O’Sullivan, M., Percy, M., \& Stewart, J. (2008). Australian evidence on corporate governance attributes and their association with forward-looking information in the annual report. Journal of Management and Governance, 12(1), 5-35.

Omer, W. K. H., Aljaaidi, K. S., \& Nasser, A. M. (2020). The Presence of Controlled Family Members on the Board, Board Size, Board Meetings and Audit Quality in the Kingdom of Saudi Arabia. International Journal of Business, 25(4), 382398 .

Omran, M. M., Bolbol, A., \& Fatheldin, A. (2008). Corporate governance and firm performance in Arab equity markets: Does ownership concentration matter?. International Review of Law and Economics, 28(1), 32-45.

Raghunandan, K., \& Rama, D. V. (2007). Determinants of audit committee diligence. Accounting Horizons, 21 (3), $265-279$.

Rahman, M. M., Meah, M. R., \& Chaudhory, N. U. (2019). The impact of audit characteristics on firm performance: an empirical study from an emerging economy. The Journal of Asian Finance, Economics, and Business, 6(1), 59-69 .

Rahmat, M. M., Iskandar, T. M., \& Saleh, N. M. (2009). Audit committee characteristics in financially distressed and nondistressed companies. Managerial Auditing Journal, 24(7).

Sharma, V., Naiker, V., \& Lee, B. (2009). Determinants of audit committee meeting frequency: Evidence from a voluntary governance system. Accounting Horizons, 23(3), 245-263.

Thiruvadi, S. (2012). Gender differences and audit committee diligence. Gender in Management: An International Journal, 24(7).

Ward, A. J., Brown, J. A., \& Rodriguez, D. (2009). Governance bundles, firm performance, and the substitutability and complementarity of governance mechanisms. Corporate Governance: An International Review, 17(5), 646-660.

Yin, F., Gao, S., Li, W., \& Lv, H. (2012). Determinants of audit committee meeting frequency: evidence from Chinese listed companies. Managerial Auditing Journal, 27(4), 425-444.

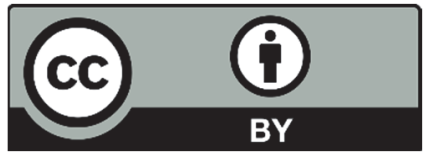

(C) 2021 by the authors; licensee Growing Science, Canada. This is an open access article distributed under the terms and conditions of the Creative Commons Attribution (CC-BY) license (http://creativecommons.org/licenses/by/4.0/). 